\title{
TOMASZ KNAPIK
}

(Katowice)

\section{PRAGMATYZM W POLSCE - WCZESNE REAKCJE, PIERWSZE WZMIANKI}

Na przełomie XIX i XX wieku William James (1842-1910), jako główny propagator nowego prądu filozoficznego, publikuje swoje główne dzieła ${ }^{1}$. Tymczasem już w pierwszych latach XX wieku pragmatyzm jest już koncepcją filozoficzną ogólnie rozpoznawalną na kontynencie europejskim. Wtedy też wydawało się, iż filozoficzne poglądy Jamesa owładną ludzkimi umysłami, a w każdym razie przez szereg lat będą posiadać decydujący wpływ na rozwój filozofii na starym kontynencie, w tym także na ziemiach polskich. Niewątpliwie pragmatyzm określał stanowisko filozoficzne wielu myślicieli. Jedni z nich identyfikowali się z głoszonymi przez Jamesa poglądami filozoficznymi, natomiast inni w opozycji do nich formułowali swoje stanowisko. „Równie $\dot{z} w$ Polsce pragmatyzm wywołał w tym czasie pewien oddźwięk, interesowat sie nim Stanisław Brzozowski, pod jego wptywem pozostawat Florian Znaniecki w poczatkowym okresie swojej działalności naukowej, gdy interesowat sie filozofia i wspominat o nim Władysław Biegański" 2. Tymczasem jak podaje Hanna Buczyńska-Garewicz „....) to wielkie zainteresowanie pragmatyzmem, jego bogata i różnorodna recepcja, kończy sie wraz z pierwsza wojna światowa. W okresie międzywojennym już inne kierunki wysuwaja się na czoło, pragmatyzm zostaje usunięty w cien" ${ }^{3}$.

\footnotetext{
1 Popularne wykłady z filozofii na temat pragmatyzmu były wygłaszane przez W. Jamesa w Instytucie Lowella w Bostonie w listopadzie i grudniu 1906 r., a także w styczniu r. 1907 w Columbia Uniwersity, w Nowym Jorku. Pragmatyzm rozwinął się z empiryzmu angielskiego. Charles Sanders Peirce (1839-1914) wyłożył nową ideę w 1878 roku w artykule pt. Jak wyobrażenia nasze uczynić jasnymi.

2 H. Buczyńska-Garewicz, James, Warszawa 1973, s. 47-48.

3 H. Buczyńska-Garewicz, Wartość i fakt. Rozważania o pragmatyzmie, Warszawa 1970, s. 15.
} 
W świetle powyżej przytoczonych słów można zadać sobie następujące pytanie: co spowodowało, że to właśnie pragmatyzm, a nie inne prądy filozoficzne wzbudziły żywe zainteresowanie wśród polskich intelektualistów. Czy była to tylko chwilowa moda? Czy może filozoficzne koncepcje zrodzone za oceanem dawały nowe rozwiązania starych kwestii.

$\mathrm{Na}$ jedną z przyczyn owego zainteresowania pragmatyzmem wskazał Władysław Tatarkiewicz (1886-1980), który pisze, że pragmatyzm zrodził się w opozycji do idealizmu racjonalistycznego i metafizycznego, proponując bardziej trzeźwy i praktyczny sposób myślenia ${ }^{4}$. Ważne zagadnienia znalazły swoje nowe rozwiązania, w tym problem relacji występujących między myślą a działaniem. Istotną przyczyną, dla której wzrastało zainteresowanie pragmatyzmem, było także wskazanie przez twórców nowego nurtu filozoficznego na człowieka, jako główny przedmiot filozofowania.

W sposób szczególny zwrot w kierunku człowieka akcentował angielski filozof Ferdinand Schiller (1864-1937). W jednej ze swoich rozpraw pt. Platon czy Protagoras autor staje po stronie Protagorasa i przyjmuje za własne znamienne słowa mówiące o tym, że to człowiek jest miarą wszystkich rzeczy i jednocześnie czyni go centrum swoich zainteresowań. Schiller zakładał, że umysł człowieka ma czysto praktyczną funkcję, to znaczy, że nie ma myśli czysto teoretycznej, lecz każda przesiąknięta jest ludzkim pragnieniem i ludzką wiarą. Takie nastawienie do rzeczywistości negowało zasady głoszone przez zwolenników naturalizmu i prowadziło w kierunku personalizmu. Tym samym jednym z postulatów podnoszonych przez owego myśliciela było uczłowieczenie świata, zaś swoje stanowisko filozoficzne nazwał humanizmem ${ }^{5}$. Ów humanizm głosił, że człowiek jest przedmiotem poznania. Przedstawiciele anglo-amerykańskiego pragmatyzmu podkreślali także możliwości człowieka jako poznającego i działającego podmiotu. Pragmatyzm dostrzegał i pojmował przy tym człowieka w jego nierozerwalnej jedności, na którą składają się sfery rozumu, emocji i woli. Powyższa teza miała przy tym niezwykle radykalny charakter, obowiązuje ona zarówno w zakresie praktycznym, jak i na terenie nauki. Stąd prawda nigdy nie ma czystego rozumowego charakteru, nie powstaje nigdy ze względu na nią samą, lecz posiada zawsze zabarwienie irracjonalno-wolicjonalne. Prawda bowiem musi człowiekowi służyć. Pragmatyzm głosi zatem tylko ten jeden rodzaj prawdy - prawdę utylitarną, użyteczną. Zatem idee ani nie są prawdziwe, ani też fałszywe, one po prostu są. O prawdziwości decyduje ich przydatność dla konkretnego podmiotu w konkretnej sytuacji. „Prawda przytrafia się idei - pisze James - staje się ona prawdziwa, okoliczności czynia ja

4 W. Tatarkiewicz, Historia filozofi, t. III, Warszawa 1999, s. 194.

5 Por. F. Copleston, Historia filozofi, t. VII, przeł. J. Łoziński, Warszawa 1989, s. 353-358. 
taka" ${ }^{6}$. Pragmatyzm w odróżnieniu od innych nurtów filozoficznych, które w pierwszych dekadach XX wieku odgrywały istotna rolę na polu filozofii, to kierunek, który postuluje praktyczny sposób myślenia i działania w każdej sytuacji, uzależniając prawdziwość twierdzeń od ich praktycznych implikacji, a więc przyjmuje użyteczność za kryterium prawdy. Tym samym praktyczne działanie człowieka staje się jedną z naczelnych kategorii refleksji pragmatycznej. W koncepcji pragmatycznej to człowiek rozstrzyga co jest prawdą, a co fałszem. „Z doktryny tej wynika, że twierdzenie, którego wartość logiczna jest relatywna nie tylko $w$ stosunku do jednostki, ale, co więcej, do określonych okoliczności i momentów, $w$ jakiej sie je wypowiada, może się okazać prawda lub fatszem w zależności od danej jednostki $i$ od ogółu potrzeb określajacych $w$ danej chwili jej aspiracje. «Być prawdziwym» nie oznacza bynajmniej: pozostawać w zgodności z rzeczami jako wzorem preegzystujacym, do którego wiedza nasza mogłaby być odnoszona i z którym mogłaby być porównywana; «być prawdziwym» oznacza: spetniać kryterium użyteczności" 7 .

A zatem pragmatyzm jest tym kierunkiem filozoficznym, w którym człowiek urzeczywistnia się w działaniu, a prawda jest funkcją skuteczności tego działania. Tym samym prawdą w pragmatyzmie staje się sam człowiek ze wszystkimi swymi indywidualnymi przymiotami. Nie były to jedyne przyczyny, jakkolwiek istotne, dla których nowo rozwijający się ruch filozoficzny w szybkim tempie został rozpowszechniony i także zdobył popularność w kręgach intelektualistów polskich.

Przyznać jednak należy, iż recepcja nowego prądu filozoficznego na ziemiach polskich była utrudniona. Mimo to polscy uczeni byli zorientowani w głównych założeniach pragmatyzmu. Wiedzę w tym zakresie zdobywali najczęściej odbywając studia w zachodnich ośrodkach uniwersyteckich. To tam najczęściej dochodziło do spotkań ze zwolennikami pragmatyzmu. Nie bez znaczenia dla głoszenia idei pragmatycznych były międzynarodowe konferencje naukowe, w tym Trzeci Międzynarodowy Kongres Filozoficzny, który się odbył w Heidelbergu, w dniach od 31.08 do 5.09.1908 roku.

Głoszone przez Jamesa i Schillera idee współtworzyły i współkształtowały rodzimą myśl filozoficzną, prowokowały do dyskusji, refleksji koncentrujących się na człowieku i na jego wytworach. Jednakże, aby mogło dojść do owych dyskusji, niezbędnym było zapoznanie polskiego czytelnika z założeniami pragmatyzmu oraz humanizmu. Jedynym środkiem, który mógł w tym celu zostać wykorzy-

6 W. James, Pragmatyzm, przeł. W. M. Kozłowski, Warszawa 1911, s. 110. Por.: „Prawda jest określeniem wszystkich przekonań, co do których praktyka dowiodła, że dobrze jest je posiadać i to z jasnych, konkretnych powodów", W. James, Pragmatyzm. Nowa nazwa kilku starych metod myślenia. Popularne wykłady z filozofii, przeł. M. Filipczuk, Kraków 2004, s. 38.

7 L. Kołakowski, Kultura i fetysze, Warszawa 2000, s. 50. 
stany - to prasa oraz publikacje książkowe, których było niewiele. Nie bez znaczenia były także tłumaczenia na język polski tych dzieł i rozpraw, które przyczyniały się do zdobywania licznych sympatyków nowej filozofii wśród polskich intelektualistów. Na łamach Myśli i Życia, Tygodnika Polskiego, Przegladu Filozoficznego publikowane były artykuły informujące i przybliżające czytelnikowi założenia filozofii pragmatycznej. Jednym z propagatorów pragmatyzmu na gruncie polskim, którego zasługi w tej dziedzinie są nie do przecenienia, a który nie został wymieniony przez Buczyńską-Garewicz, był Władysław Mieczysław Kozłowski (1858-1935). Jego rola w upowszechnianiu idei pragmatycznych na ziemiach polskich jest istotna. Kozłowski zetknął się z pragmatyzmem jako czynny uczestnik międzynarodowych kongresów filozoficznych, które odbywały się na przełomie wieków, w tym Trzeciego Międzynarodowego Kongresu Filozoficznego, który - jak już wspomniano - odbył się w 1908 roku w Heidelbergu ${ }^{8}$.

W jednym z artykułów prasowych opublikowanych w 1913 roku, tak oto na temat pragmatyzmu wypowiada się ów uczony: „Nam nie pozostało nic więcej, jak pogodzić się z tym nieuniknionym wynikiem naszego usposobienia umysłowego $i$ przyjmujac już uobywatelniona nazwę, zaciagnać się $w$ ten sposób $w$ szeregi rosnacego ruchu, znanego pod nazwa pragmatyzmu" 9. Przy czym jak podaje we wspomnianym artykule jego autor, to nie kto inny, ale „F. C. S. Schiller jest jednym z najbardziej czynnych szermierzy pragmatyzmu, a termin humanizm, który zastapić usituje utarta już nazwe nowej doktryny, oznacza takize pewien jej odcień, odbiegajacy zarówno od pomystu pierwotnego Pears'a, jak i od pragmatyzmu James'a" ${ }^{10}$. W treści tegoż artykułu Kozłowski charakteryzuje podstawowe założenia humanizmu Schillera. Czytamy w nim między innymi, że współtwórca

8 Por.: W.M. Kozłowski, Sprawozdanie z Trzeciego Kongresu Międzynarodowego Filozoficznego - Heidelberg, [w:] „Przegląd Filozoficzny”, 1908, r. XI, s. 335-336. Autor tegoż artykuły, jako uczestnik Kongresu, który się odbył w dniach: 31 sierpnia - 5 września 1908 roku w Heidelbergu, przybliża polskiemu czytelnikowi zasady, które czynią pragmatyzm odmiennym nurtem filozoficznym, od tych, które były znane na kontynencie europejskim. Pragmatyzm ,jest doktryną, według której prawdy są wartościami logicznymi, (...) prawdziwość twierdzenia zależy od jego zastosowania, (...) znaczenie prawidła polega na jego zastosowaniu, (...) wszelkie znaczenie zależy od celu, (...) wszelkie życie umysłowe jest intencyjne, (...). Pragmatyzm jest także protestem przeciw krańcowej przeciwności naturalizmu - przeciw idealizmowi absolutystycznemu; jest protestem systematycznym przeciw każdemu zapoznaniu charakteru intencyjnego wszelkiego prawdziwego poznania. (...) Pragmatyzm jest więc świadomym zastosowaniem do logiki lub epistemologii psychologii teleologicznej, postulującej w ostatniej analizie metafizykę woluntarystyczną. Metoda pragmatyzmu jest więc empiryczną, teleologiczną i konkretną. Duch jego jest humanistyczny".

9 W. M. Kozłowski, Czym jest humanizm polski, [w:] „Myśl i Życie”, 1913, nr 5, s. 12. Por. także tegoż, Zasady humanizmu polskiego, [w:] „Myśl i Życie”, 1913, nr 6-7, 1912, nr 11, także, Pragmatyczna rewizja logiki, [w:] „Myśl i Życie”, 1912, nr 2-3, także, Prawda formalna i logika F. C. S. Schiller, [w:] „Tygodnik Polski” 1912, nr 12.

10 W. M. Kozłowski, F. C. S. Schiller i jego humanizm, [w:] „Tygodnik Polski”, 1912, Rok I, nr 11 , s. $167-170$. 
pragmatyzmu odrzuca monizm, jak i dualizm w metafizyce. Świat przedstawia się jako mnogość monad, zostających pod kierunkiem monady - boga, ograniczonego w swej władzy, usiłującego doprowadzić do harmonii chaos bytów indywidualnych. Usiłowania te wytwarzają materialny świat zjawiskowy i również zjawiskową jaźń poszczególnych monad ${ }^{11}$. Nie bez znaczenia było także to, iż w miesięczniku „Myśl i Życie" stanowisko redaktora piastował Kozłowski, który jednocześnie był także jego wydawcą. To na łamach tego miesięcznika publikował swoje artykuły, a także udostepniał szpalty innym, którzy byli zainteresowani publikowaniem rozpraw dotyczących filozofii pragmatycznej. W jednym z numerów miesięcznika „Myśl i Życie" z 1912 roku Kozłowski w napisanym przez siebie artykule pt.: Humanizm współczesny i filozofia narodowa oznajmił, że miesięcznik którego jest redaktorem, akceptuje zasady humanizmu, rozwija je i szerzy, zaś ruch ten uważa za filozofię narodową polską ${ }^{12}$. W tym samym numerze autor wspomnianego oświadczenia zapoznaje czytelnika ze znaczeniem słowa humanizm. I tak w wieku XVII, jak stwierdził Kozłowski, humanizm był zwrotem od rzeczy pozaświatowych ku ziemskim, a w szczególności koncentrował się na człowieku. Wtedy to człowiek stał się głównym przedmiotem badań, ale co istotne, badaniom tym towarzyszyła myśl, że wiedza jest dla człowieka. W pierwszych latach dwudziestego wieku jednym z zadań, które stało przed humanizmem było odrzucenie dogmatyzmu naukowego z jego determinizmem. Cechą charakterystyczną tak rozumianego humanizmu jest znalezienie oparcia w pozytywizmie, materializmie oraz innych prądach umysłowych, które szukały swych podstaw w przyrodoznawstwie ${ }^{13}$. Jakkolwiek Kozłowski był oddanym propagatorem idei pragmatyzmu i humanizmu na gruncie polskim, nie znaczy to jednak, że całość poglądów James'a i Schillera przyjmował bezkrytycznie. Dość wspomnieć, iż to Kozłowski dokonał przetłumaczenia dzieła amerykańskiego filozofa pt. Pragmatyzm. Dylematy determinizmu. Tłumaczenie dzieła zostało opublikowane w 1911 r. ${ }^{14}$ Polski uczony nie ograniczał się tylko do publikowania swoich artykułów w miesięczniku, którego był redaktorem. Swoje artykuły ogłasza także na łamach „Przeglądu Filozoficznego”. W jednym z nich dokonuje charakterystyki poglądów Schillera, a ściślej założeń filozoficznych angielskiego uczonego zawartych w rozprawie pt.: Platon czy Protagoras? ${ }^{15}$.

\footnotetext{
11 Tamże, s. 167-168.

12 W. M. Kozłowski, Humanizm wspólczesny i filozofia narodowa, [w:] „Myśl i Życie”, 1912, nr 5, s. 126 .

13 Tamże, s. 117.

14 Patrz. W. James, Pragmatyzm, przeł. W. M. Kozłowski, Warszawa 1911. We wstępie do przekładu znalazło się tłumaczenie krótkiego listu, który został napisany przez W. Jamesa do W. M. Kozłowskiego, z datą 27.01.1910 r.

15 W. M. Kozłowski, F. C. S. Schiller. Plato or Protagoras?, [w:] „Przegląd Filozoficzny”, 1919, (Rocznik XII), s. 352-355.
} 
Czerpiąc filozoficzne inspiracje z koncepcji angloamerykańskich pragmatystów Kozłowski swoje poglądy, które nazywa humanizmem polskim, charakteryzuje w następujących punktach: „1-Filozofia nie jest dzietem samego intelektu. Wytwory rozumu nie moga powstać w sprzeczności z innymi sferami naszej osobowości, tj. uczuciem i wola. 2-Chociaż filozofia bazuje na catej osobowości człowieka, to jest ona jednak wiedza - musi zatem swa ostateczna forme przybrać od rozumu. 3 - Wiedza musi kierować wyborem środków dla urzeczywistnienia celów człowieka. Jeśli jej wszakíe przypada taka rola, to inne źródła niż rozum musza mieć ideaty ludzkie. 4 - Jaźn teoretyczna i praktyczna sa równouprawnione. Stanowisko to przeciwstawia się dogmatyzmowi naukowemu, który opiera się tylko na postulatach poznawczych wiedzy. 5 - Na równi stawiać należy determinizm naukowy $i$ zasade wolności czlowieka. Sfera duchowa jednostki nie podlega prawom przyrodniczym i stanowi warunek jej aktywności. 6 - Wszystkie wartości cywilizacji istnieja tylko dla i przez człowieka - jest on więc ostatecznym miernikiem wartości. 7 - Wszystkie te wartości wytwarzaja jedność osobników ludzkich, zaś środkiem spajajacym ich jest w głównej mierze język" ${ }^{16}$. Na temat inspiracji filozoficznych redaktora miesięcznika „Myśl i Życie” wypowiedział się Zygmunt Zawirski (1882-1948). W jednej ze swoich publikacji pisze on: „W swoich pogladach teoretycznych Kozłowski przedstawia pewna synteze pozytywizmu z neokantyzmem $i$ swoiście rozumianym pragmatyzmem. Kozłowski wyszedt z pozytywizmu, ale pod wplywem filozofii Kanta dojrzał dogmatyzm założen pozytywizmu i postanowit go od tego dogmatyzmu uwolnić, wskazując na subiektywne źródło praw przyrody. (...) Jeśli w dalszym ciagu Kozłowski przyznawat się do pewnej wspólności z pragmatyzmem, to byta to znowu taczność bardzo luźna, wynikajaca tylko z ogólnego hasta filozofii czynu, a nie mająca nic wspólnego z biologicznym kryterium prawdy, wysuwanym przez pragmatyzm" ${ }^{17}$. Z kolei Bolesław Andrzejewski słusznie zauważa, że w poglądach Kozłowskiego istnieją punkty styczne z poglądami pragmatystów. Opinia ta została wypowiedziana w odniesieniu do koncepcji prawdy. „W problematyce tej widać - jak pisze Andrzejewski - wyraźne zbieżności autora „Zasad przyrodoznawstwa" z doktryna angloamerykanskiego pragmatyzmu. Widać tu wszakże wyraźnie odstęstwo od filozofii Jamesa i F. C. S. Schillera, co wyraża się w podkreślaniu czysto intelektualnego charakteru prawdy $i$ przeciwstawianiu jej «prawdom życia», bazujacym na uczuciu $i$ woli" ${ }^{18}$. Przytoczone powyżej dwie

16 W. M. Kozłowski, Zasady humanizmu polskiego, [w:] „Myśl i Życie”, 1913, nr 6-7.

17 Z. Zawirski, Wtadystaw Mieczystaw Kozłowski. Wspomnienie pośmiertne, (odbitka z XXXVIII rocznika „Przeglądu Filozoficznego”), Warszawa 1935, s. 252.

18 B. Andrzejewski, Poglady filozoficzne Wladystawa M. Koztowskiego, Poznań 1979, s. 67, por. także: M. Milczarek, Tożsamość etyczna jednostki w aspekcie umowy spolecznej w twórczości wybranych polskich filozofów, [w:] Filozofia tożsamości, pod red. J. Kojkoł, Gdańsk 2007, s. $79-91$. 
opinie wskazują na to, że jakkolwiek Kozłowski był zwolennikiem filozofii pragmatycznej, to jednak nie sposób odmówić jego poglądom pewnego rodzaju odmienności i oryginalności. Jednakże to, co godne uwagi w postawie polskiego uczonego to praca, którą wykonał na rzecz przybliżenia polskim intelektualistom zasad, założeń pragmatyzmu ${ }^{19}$.

Kolejnym polskim uczonym, który był zainteresowany oraz pozostawał w kręgu oddziaływań idei związanych z humanizmem był Stanisław Brzozowski (1878-1911). W jednym z artykułów recenzujących prace Brzozowskiego, które zostały opublikowane w pierwszych latach XX wieku, jego autor pisze „...w tym czasie Brzozowski pozostawał głównie pod urokiem filozofa angielskiego, F. C. S. Schillera, który należat do pragmatystów, a reprezentowany przez siebie kierunek filozoficzny nazywał humanizmem" 20. Istotnie, Brzozowski był żywo zainteresowany rozwojem ruchu pragmatycznego w Polsce. W Legendzie Młodej Polski tak oto wypowiada się na ten temat: „Wszystko, co stanowi treść naszej myśli, wszystkie nasze pojęcia, cała nasza «teoria»- wszystko to sa narzędzia naszej praktyki. Czynność nasza wytworzyła to wszystko i sa to jej perspektywy i plany. (...) W zetknięciu z kazda forma bytowej filozofii (...) pragmatyzm tryumfować musi. I tryumf ten można powitać z radościa, jest to zwycięstwo czynnego, wytwórczego wspólżycia ludzkości nad różnymi formami klerykalnego i teologicznego ducha" 21. Ta pełna optymizmu wypowiedź wieszcząca zwycięstwo pragmatyzmu, była poprzedzona wnikliwą analizą poglądów głoszonych przez Schillera oraz Jamesa. W przytoczonej wypowiedzi znalazły się także słowa krytyki, które były skierowane pod adresem pragmatyzmu. Mimo pewnych zastrzeżeń Brzozowski z sympatią odnosił się do nowego ruchu filozoficznego. To, co w sposób szczególny wzbudziło zainteresowanie autora Legendy Młodej Polski w pragmatyzmie i uczyniło przedmiotem refleksji filozoficznej, to założenie, według którego człowiek pozostaje twórcą świata i siebie samego. W jednym ze swoich artykułów Brzozowski w sposób następujący dokonuje charakterystyki stanowiska humanistycznego: „Ani Bóg, ani natura nie rzadzi nami, ludzkość jest samowładna. Wszystko, co nas otacza, nawet to, co ukazuje sie nam, jako niezależna, pozaludzka rzeczywistość jest naszym, ludzkim wytworem. «Poza soba i ponad soba ludzkość otacza mrok i próżnia. Lecz nie jest to pobudka do rozpaczy. Lecz wezwanie do twórczego męstwa. Próżnia ta znaczy, że ludzkość jest pania swych losów». Ale też dlatego jest czas żywota dla ludzi silnych, dla ludzi, którzy radośnie i dumnie powiedza: „jesteśmy sami, a więc wszystko do nas należy. Ci, którym do życia

19 W. M. Kozłowski, Przeglad Systematów Wspótczesnych. Pragmatyzm, [w:] „Przegląd Filozoficzny", rok 1911 (rocznik XIV), s. 4-79.

20 H. Życzyński, Stanisław Brzozowski. Kultura i Życie, Lublin 1936, s. 8.

21 S. Brzozowski, Legenda Mlodej Polski, Warszawa 1937, s. 76-77. 
potrzeba jakiegokolwiek przeznaczenia, którzy potrzebuja Boga, Przyrody, Dziejów jako obiektywnych instancji, wydajacych nakazy i chroniacych człowieka od ciężaru odpowiedzialności swobodnej, tacy ludzie nie zrozumieja nigdy wielkości humanizmu; nie zaznaja też nigdy rozkoszy wolnego czynu" ${ }^{22}$. Z treści przytoczonego cytatu jednoznacznie wynika, że jego autor identyfikował się z ideami głoszonymi przez pragmatystów. Poglądy te utwierdzały go w powziętych przekonaniach, które dotyczyły przede wszystkim człowieka oraz jego miejsca i roli, jaką powinien odgrywać w świecie.

Na temat tego, co charakteryzowało poglacdy Brzozowskiego, wypowiedział się Bogdan Suchodolski (1903-1992). Podaje on, że „Brzozowski był apostołem idei twórczości ludzkiej. Piętnował zawsze wszelkie postacie duchowego i fizycznego lenistwa, ujawniat nieubłaganie $i$ bezlitośnie, iż nie ma dla nas nigdzie trwałych punktów oparcia, krzepiacych, zacisznych rękojmi naszego powodzenia, przekonywat, iz wszystko zawisło od ludzkiej woli, wysiłku, pracy i odpowiedzialności. Ale zarazem głosit, iż życie nie jest zupełna dowolnościa, ostrzegał przed tatwizna wygodnych marzen" ${ }^{23}$. Postulat, by uznać samego siebie za kreatora własnej osobowości i świadomości, i rzeczywiście nim być, jest jednym z podstawowych wymagań, jakie - zdaniem Brzozowskiego - stoją przed człowiekiem. „Zapanować nad samym soba, siebie samego tworzyć, być artysta $i$ twórca wtasnego przeznaczenia, siebie samego znać $i$ posiadać $w$ ten sposób może tylko nowoczesny Europejczyk: taka jest siła fatalna tkwiaca $w$ naszym pozornie osobistym, izolowanym ja" 24. Wymaganie to pozostaje centralną ideą kultury europejskiej, zmierzającej do „podniesienia człowieka do godności swobodnego sprawcy swoich losów" 25. Brzozowski przyjmuje humanistyczny pogląd na świat i zakłada, iż najwyższą wartością w świecie jest człowiek. Jest on zobowiązany do podejmowania nieustannych wysiłków w celu świadomego współtworzenia historii oraz do przekształcania siebie z przypadkowego produktu okoliczności w rozumny twór własnego sumienia.

Sposób, w jaki pragmatyzm stawiał zagadnienia, rozwiązywał problemy filozoficzne, był bliski Brzozowskiemu. Niejednokrotnie sam dał wyraz swoim sympatiom kierowanym pod adresem humanizmu, który był dla niego inspirującym ruchem filozoficznym. Brzozowski w sposób konsekwentny nie rozwinął koncepcji

22 Por. B. Suchodolski, Stanisław Brzozowski. Rozwój ideologii, Warszawa 1933, Biblioteka Pamiętnika Literackiego t. I, s. 62-281. Por. także: B. Suchodolski, Rękopisy Stanistawa Brzozowskiego, [w:] „Ruch Literacki”, 1935 nr 5, s. 142-143.

23 Tamże. s. 272.

24 St. Brzozowski, Dziela, t. VIII, (Legenda Mtodej Polski. Studia o strukturze kulturalnej), Warszawa 1937, s. 9.

25 Tamże, s. 10. 
związanych z humanizmem, któremu tak dużo zawdzięczał. Jak pisze Suchodolski „Uczynił to dopiero Znaniecki, właściwy twórca filozofii humanistycznej w Polsce. Jego studia podejmuja myśl Brzozowskiego w całej pełni" 26.

Florian Znaniecki (1882-1958) niezwykle wysoko cenił poglądy głoszone przez pragmatystów, a także dostrzegał w pragmatyzmie korzystny kierunek rozwoju filozofii.

W drodze do spotkania z pragmatyzmem Znaniecki przechodził różne koleje losu. Wśród pozostawionych wspomnień, traktujących o latach młodzieńczych, brak jest jakichkolwiek wzmianek na temat pragmatyzmu. Najwidoczniej na tym etapie życia młody literat nie zwracał uwagi na docierające z zachodu informacje traktujące o filozofii pragmatycznej, a także humanizmie Schillera. Natomiast w bibliografii do pracy doktorskiej nie brakuje już dzieł Jamesa pt.: Pragmatism oraz Will to Believe ${ }^{27}$. Wynika z tego, że pierwsze kontakty, do jakich doszło z pragmatyzmem, miały miejsce podczas studiów w Szwajcarii i Francji, gdzie Znaniecki poświęcił swój czas na przestudiowanie głównych dzieł Jamesa. Do kraju powrócił jako ten, dla którego pragmatyzm nie był już żadną nowością, a także nie krył w sobie żadnych tajemnic. Co prawda rok 1910 nie obfitował we wzmianki na temat stosunku, jaki żywił do pragmatyzmu. Pierwsze opinie na ten temat pojawią się w niedalekiej przyszłości. W lipcu 1911 roku w czasopiśmie literacko-artystyczno-naukowym „Sfinks” Znaniecki nie pozostawia czytelnikowi żadnych wątpliwości co do stanowiska, jakie zajmuje wobec humanizmu reprezentowanego przez Schillera oraz pragmatyzmu Jamesa. Czytamy tam między innymi: „...humanizm jest istotnie dzisiaj potężnym pradem, z którym filozofia liczyć sie musi więcej, niż z jakimkolwiek innym" ${ }^{28}$.

Pod koniec pierwszej dekady dwudziestego wieku Znaniecki, czego sam nie ukrywał, znajdował się pod przemożnym wpływem filozofii Jamesa oraz Schillera. Ten wpływ daje się zauważyć w jego artykułach opublikowanych w latach 1911-1912. Mam tutaj na myśli przede wszystkim artykuł pod tytułem Humanizm w filozofii wspótczesnej oraz pracę Humanizm i poznanie, która została wydana drukiem w 1912 roku. We wspomnianych powyżej publikacjach sam autor identyfikuje się z głoszonymi przez filozofów pragmatystów ideami. W wyeksponowaniu zagadnienia wartości oraz twórczości Znaniecki widział największą zasługę no-

26 B. Suchodolski, Stanistaw Brzozowski. Rozwój ideologii, wyd. cyt., s. 72.

27 Wiosną 1910 roku w Krakowie, na podstawie rozprawy zatytułowanej Zagadnienie wartości $w$ filozofii Znaniecki uzyskuje tytuł doktora. Kraków podobne jak Paryż i Genewa był kolejnym przystankiem w życiu uczonego, który miał aspiracje rozpoczęcia samodzielnej kariery naukowej w dziedzinie filozofii na jednym z polskich uniwersytetów.

28 F. Znaniecki, Humanizm w filozofii wspólczesnej, [w:] „Sfinks”, 1911, z. 43, s. 310-311. 
wego prądu filozoficznego ${ }^{29}$. Natomiast pragmatyzm traktowany był przez autora Humanizmu i poznania jako powrót do tradycji filozofii greckiej, łączącej w sobie mądrość i cnotę.

Z pewnością w kwestii uznania kogoś za ucznia takiego czy innego ruchu filozoficznego mogą rodzić się pytania i budzić wątpliwości. Jednakże wątpliwości te znikaja w przypadku ustalenia filozoficznych inspiracji, które młody filozof czerpał z pragmatyzmu ${ }^{30}$.

Sam Znaniecki w 1919 roku napisał: „Wśród moich późniejszych długów żaden nie jest równie wielki jak ten, który jestem winien pragmatyzmowi - jestem skłonny $w$ istocie uważać sie niemal za ucznia tego kierunku. Nie będe zdziwiony, jeśli mistrzowie wypra się mnie, ponieważ nie mogę podzielać większości ustalonych pogladów pragmatystycznych na szczegółowe zagadnienia filozoficzne, takich jak: biologiczna koncepcja działalności, instrumentalna definicja prawdy $i$ wiele innych. Wydaje mi się, że ogólny prad myślowy, któremu pragmatyzm dat poczatek, jest zbyt potężny, zbyt rozległy $i$ zbyt głęboki, by miat on być uregulowany z góry przez kilka już przyjętych przez szkołe formut. Zostać pragmatysta ortodoksyjnym - znaczyłoby obecnie poświęcić ducha dla litery" ${ }^{31}$.

Odmienne stanowisko w odniesieniu do idei pragmatycznych zajmował Władysław Biegański (1857-1917). Myśliciel ten poddał krytyce główne założenia pragmatyzmu, a w szczególności poglądy traktujące o prawdzie. Jednakże, na co zwraca uwage Stanisław Borzym, swoją koncepcję teoriopoznawczą zwaną prewidyzmem, sformułował zarówno w dyskusji z pragmatyzmem jak i empiriokrytycyzmem ${ }^{32}$. Biegański, który słusznie pozostaje identyfikowany z zawodem lekarskim, koncentrował swoje zainteresowania przede wszystkim na logice i zagadnieniach teoriopoznawczych. Jest autorem dzieł pt. Zasady logiki ogólnej wydanej w 1903 r., Teorii logiki opublikowanej w 1912 r. Tym samym to między innymi zagadnienia logiczne były tymi, którym autor wspomnianych dzieł poświęcił znaczną część swojego życia. Mimo to, ów lekarz-humanista śledził powstające prądy intelektualne, był zaznajomiony z założeniami pragmatyzmu Jamesa oraz humanizmu Schillera. Jednak nie wypowiadał się na temat tych nurtów z entuzjazmem. Ostrze swojej krytyki zwrócił w kierunku rozwiązań jakie pragmatyści zastosowali w odniesieniu do zagadnienia prawdy. Jak pisze autor Teorii logiki

29 „Ten ogólny kierunek można by nazwać (...) humanizmem; główne zagadnienie zaś, do którego wszystkie inne zaczynają być sprowadzone, to zagadnienie wartości, a zwłaszcza pewna jego część: zagadnienie działalności", F. Znaniecki, Humanizm i poznanie, Warszawa 1912, [w:] Pisma filozoficzne, t. II, Warszawa 1991, s. 239.

30 Por.: S. Borzym, Trzy źródla filozofii Floriana Znanieckiego, [w:] Panorama polskiej myśli filozoficznej, Warszawa 1993, s. 190-196.

31 F. Znaniecki, Rzeczywistość kulturowa, [w:] Pisma filozoficzne, t. II, Warszawa 1991, s. 472.

32 Por.: S. Borzym, Bergson a przemiany światopogladowe $w$ Polsce, Wrocław 1984, s. 44-47. 
„Zagadnienie to stało się nawet ośrodkiem, około którego grupowaty się nowe lub odnowione poglady filozoficzne o odrębnej treści znane pod ogólna nazwa pragmatyzmu lub humanizmu i liczace wielu zwolenników zwłaszcza w Anglii i Ameryce ${ }^{33}$. Tak oto na temat głoszonej przez pragmatystów koncepcji prawdy wypowiada się Biegański: „Pragmatysta James określa prawdę w następujacy sposób: „prawda jest ogólna nazwa dla aktów sprawdzania ... a sprawdzanie oznacza pewne praktyczne skutki idei sprawdzonych (...). Inny zwolennik tego kierunku filozoficznego, Schiller, mówi wprost „prawda sądu zależy od jego zastosowania” 34 . Przytoczone definicje prawdy tak jak je rozumiał James oraz Schiller - jak stwierdza polski uczony - nie mają żadnego znaczenia dla logiki, a nawet burzą naukę o logice ${ }^{35}$. Jednoznaczna krytyka zagadnienia prawdy, jednego z podstawowych zagadnień w filozofii, nie pozostawia żadnych wątpliwości, że polski myśliciel do sympatyków pragmatyzmu się nie zaliczał. Należy zauważyć, iż z opiniami Biegańskiego się liczono, nawet jeśli się z nimi nie zgadzano. Do grona czytelników i recenzentów prac Biegańskiego należał między innymi wybitny polski filozof Roman W. Ingarden (1893-1970) ${ }^{36}$.

Krótki przegląd stanowisk, jakie zajmowali polscy myśliciele wobec pragmatyzmu, tego jak reagowali na ów nowo powstały prąd filozoficzny, pozwala na sformułowanie kilku uwag. Pierwszą z nich jest wyraźny brak tłumaczeń dzieł pragmatystów na język polski. Na tym tle pozostaje godnym uwagi inicjatywa podjęta przez Kozłowskiego, dotycząca tłumaczenia dzieła Jamesa pt. Pragmatyzm. Ukazanie się tego dzieła w 1911 r. było istotnym wydarzeniem na rynku księgarskim. Szczególnie ważnym dla tych, którzy z wielką sympatią spoglądali na filozofię i filozofów będących jednocześnie twórcami jak i propagatorami nowych prądów intelektualnych. Brak literatury podmiotowej spowalniał rozwój recepcji nowego prądu filozoficznego na gruncie polskim. Mimo to, wielu filozofów znało idee głoszone przez pragmatystów. W przypadku większości z nich, do pierwszych spotkań z pragmatyzmem czy też humanizmem dochodziło w ramach odbywanych studiów poza granicami kraju, bądź też w ramach podróży zagranicznych.

Rola polskich uczonych w rozwoju ruchy pragmatycznego była niewielka. W zasadzie podejmowane przez nich działania sprowadzały się do informowania i popularyzowania idei Jamesa i Schillera. Nie współuczestniczyli oni w procesach formowania się filozofii pragmatycznej. Kontaktów o charakterze koleżeńsko-naukowym z czołowymi przedstawicielami pragmatyzmu nie było. Polscy uczeni

33 Wł. Biegański, Teoria logiki, Warszawa 1912, s. 110.

34 Tamże, s. 111.

35 Tamże, s. 112, por. także, tegoż, Traktat o poznaniu i prawdzie, 1910 (b.d.b.).

36 Por. Cz. Głombik, Husserl i Polacy. Pierwsze spotkania, wczesne reakcje, Katowice 1999, s. $110-114$. 
ograniczali się do roli zewnętrznych obserwatorów nowego ruchy filozoficznego. Na uwagę zasługuje także fakt, że żaden z polskich uczonych nie napisał pracy, której celem byłaby całkowita rekonstrukcja poglądów Jamesa czy też Schillera. Niewątpliwie poprzez swoją działalność Kozłowski przyczynił się w znacznym stopniu do przybliżenia głównych myśli - poglądów głoszonych przez pragmatystów, natomiast Znaniecki oraz Brzozowski informowali czytelnika zainteresowanego nowościami filozoficznymi, o rodzącym się nowym prądzie intelektualnym zamiennie nazywanym pragmatyzmem lub humanizmem. Niewątpliwie wymienieni uczeni czerpali swoje filozoficzne inspiracje z pragmatyzmu, który ostatecznie został przez nich w pewnym sensie zasymilowany i co za tym idzie, nadał kształt ich własnym oryginalnym poglądom.

\section{Summary}

The purpose of the article "Pragmatism in Poland - first reactions, early records" is to show the process of familiarizing Polish readers with this new philosophical trend, and its reception in Poland at the beginning of the $20^{\text {th }}$ century. Polish scholars, despite the difficulties involved, were familiar with the main assumptions of pragmatism. The sources of their knowledge in this respect were most often studies conducted at western university centres. The main exponents of pragmatic ideas were: Florian Znaniecki (1882-1958), Władysław Mieczysław Kozłowski (1858-1935) and Stanisław Brzozowski (1878-1911), whereas Władysław Biegański (1857-1917) developed his views in opposition to pragmatism. However, it is necessary to point out that the role of Polish scholars in the development of pragmatism was insignificant. Kozłowski undoubtedly popularized the main ideas - views endorsed by pragmatists through his work, while the works of Znaniecki and Brzozowski were sources of information to the reader who was interested in philosophical novelties of the new intellectual movement, interchangeably called pragmatism or humanism. The mentioned scholars drew their philosophical inspirations from pragmatism, which in a sense they eventually assimilated; in consequence, pragmatism shaped their own original views.

\section{Bibliografia}

B. Andrzejewski, Poglady filozoficzne Władysława M. Kozłowskiego, Poznań 1979.

W. Biegański, Teoria logiki, Warszawa 1912.

W. Biegański, Traktat o poznaniu i prawdzie, 1910 (b.d.b.).

S. Borzym, Trzy źródta filozofii Floriana Znanieckiego, [w:] Panorama polskiej myśli filozoficznej, Warszawa 1993, s. 190-196. 
S. Borzym, Bergson a przemiany światopogladowe w Polsce, Wrocław 1984.

H. Buczyńska-Garewicz, James, Warszawa 1973.

H. Buczyńska-Garewicz, Wartość i fakt. Rozważania o pragmatyzmie, Warszawa 1970.

S. Brzozowski, Legenda Młodej Polski. Studia o strukturze kulturalnej, Warszawa 1937.

F. Copleston, Historia filozofii, przeł. J. Łoziński, t. VII, Warszawa 1989.

C. Głombik, Husserl i Polacy. Pierwsze spotkania, wczesne reakcje, Katowice 1999.

W. James, Pragmatyzm, przeł. W. M. Kozłowski, Warszawa 1911.

W. James, Pragmatyzm. Nowa nazwa kilku starych metod myślenia. Popularne wyklady z filozofii, przeł. M. Filipczuk, Kraków 2004.

L. Kołakowski, Kultura i fetysze, Warszawa 2000.

W. M. Kozłowski, Sprawozdanie z Trzeciego Kongresu Międzynarodowego Filozoficznego - Heidelberg, [w:] „Przegląd Filozoficzny”, 1908, r. XI, s. 335-336.

W. M. Kozłowski, Czym jest humanizm polski, [w:] „Myśl i Życie”, 1913, nr 5, s. 9-12.

W. M. Kozłowski, F. C. S. Schiller i jego humanizm, [w:] „Tygodnik Polski”, 1912, rok I, nr 11, s. $167-170$.

W .M. Kozłowski, Humanizm współczesny i filozofia narodowa, [w:] „Myśl i Życie”, 1912, nr 5, s. $120-126$.

W. M. Kozłowski, F. C. S. Schiller. Plato or Protagoras?, [w:] „Przegląd Filozoficzny”, 1919, (Rocznik XII), s. 352-355.

W. M. Kozłowski, Zasady humanizmu polskiego, [w:] „Myśl i Życie”, 1913, nr 6-7.

W. M. Kozłowski, Przeglad Systematów Współczesnych. Pragmatyzm, [w:] „Przegląd Filozoficzny", 1911, s. 4-79.

B. Suchodolski, Stanisław Brzozowski. Rozwój ideologii, Warszawa 1933, [w:] Biblioteka Pamiętnika Literackiego, t. I, s. 62-281.

B. Suchodolski, Rękopisy Stanisława Brzozowskiego, [w:] „Ruch Literacki”, 1935, nr 5, s. $140-143$.

W. Tatarkiewicz, Historia filozofii, t. III, Warszawa 1999, s. 194.

Z. Zawirski, Władysław Mieczysław Kozłowski. Wspomnienie pośmiertne, (odbitka z XXXVIII rocznika „Przeglądu Filozoficznego”), Warszawa 1935, s. 252.

F. Znaniecki, Humanizm w filozofii wspótczesnej, [w:] „Sfinks”, 1911, z. 43, s. 300-321.

F. Znaniecki, Humanizm i poznanie, Warszawa 1912, [w:] Pisma filozoficzne, t. II, Warszawa 1991.

F. Znaniecki, Rzeczywistość kulturowa, [w:] Pisma filozoficzne, t. II, Warszawa 1991.

H. Życzyński, Stanisław Brzozowski. Kultura i Życie, Lublin 1936.

Autor jest adiunktem w Akademii Wychowania Fizycznego w Katowicach, Zakład Filozofii i Socjologii 